\title{
Quality certificates for homeopathic matrices
}

\author{
Amarilys de Toledo Cesar, Virgínia Tereza Cegalla \\ HN Homeopatia e Produtos Naturais Ltda, São Paulo, Brazil,
}

\begin{abstract}
Background: To produce homeopathic medicines, pharmacies need raw materials (mother tinctures and diluted-agitated solutions, named "matrices"), provided by insumes suppliers. The "matrices" are ultra high dilutions and can not be tested against Analysis Reports.
\end{abstract}

Aims: to propose alternatives to the matrices Analysis Report; to contribute to the quality of homeopathic medicines and treatment.

Method: search of information present in the documentation provided from 2 national and 3 European suppliers in order to develop criteria.

Discussion: the needed concepts for compliance with the orders throughout their production process were presented. The control of information involved in the process allows to trace the production of matrices, providing an indication of the quality with which they were obtained. Each supplier gives different approach to issuing a document, calling it Certificate of Conformity Protocol Preparation, Manufacturing Certificate or Quality Certificate. Summarizing, it is a supplier's declaration, which involves the quality control of raw materials, packaging materials and of the process used, but not a report that enables customers to repeat the analysis. A model was proposed for a Certificate of Quality, with the minimum information needed to indicate to the pharmacies that there is a control of the process. This certificate shall contain statements about the process.

Conclusion: Quality Certificate seems to be the best document to ensure the pharmacy that the matrix obtained presents characteristics compatible with the preparation of a quality homeopathic medicine.

Keywords: homeopathic pharmacy; quality; homeopathy.

\section{Certificados de qualidade para matrizes homeopáticas}

\section{RESUMO}

Introdução: Para produzir medicamentos homeopáticos as farmácias necessitam de matérias primas (tinturas-mãe e matrizes), fornecidas por laboratório de insumos. As matrizes são soluções ultra diluídas e não podem ser testadas segundo Laudos de Análise. 
Objetivos: propor alternativas para o Laudo de Análises de matrizes; contribuir para a qualidade dos medicamentos e do tratamento homeopático.

Método: pesquisa de informações provenientes da documentação de 2 fornecedores nacionais e 3 europeus para desenvolvimento de critérios.

Discussão: foram abordados conceitos necessários para o atendimento do pedido ao longo de todo o processo. O controle das informações envolvidas no processo possibilita rastrear a produção das matrizes, fornecendo um indicativo da qualidade com que estas foram obtidas. Cada fornecedor dá enfoque diferente para o documento que emite, chamando de Certificado de Conformidade, Protocolo de Preparo, Certificado de Manufatura ou Certificado de Qualidade. Em resumo, é uma declaração do fornecedor, que envolve o controle de qualidade de matérias primas, do material de embalagem e do processo utilizado, mas não de um laudo que possibilita ao cliente refazer a análise. Foi proposto um modelo de Certificado de Qualidade, com as informações mínimas necessárias que indiquem à farmácia que há um controle de processo. Neste certificado devem constar declarações sobre o processo.

Conclusão: o Certificado de Qualidade parece ser o melhor documento para assegurar à farmácia que a matriz adquirida apresenta características compatíveis com a manipulação de um medicamento homeopático de qualidade.

Palavras-chave: farmácia homeopática; qualidade; homeopatia.

\section{(c) BY-NC-ND Licensed to GIRI}

Support: authors declare that this study received no funding

Conflict of interest: the authors declare there is a conflict of interest, for working in a laboratory of matrices production.

Correspondence author: Amarilys de Toledo Cesar, http://www.hncristiano.com.br amarilys@hncristiano.com.br

How to cite this article Cesar AT, Cegalla VT. Certificados de qualidade para matrizes homeopáticas. Int J High Dilution Res [online]. 2011 [cited YYYY Month dd]; 10(36): 224-225. Proceedings of the XXV GIRI Symposium and VIII CBFH; 2011 Sep 04-07; Foz do Iguaçu (Brazil). GIRI and ABFH; 2011; Available from: http://www.feg.unesp.br/ ojs/index.php/ijhdr/article/view/493/506 